\title{
INSTALACIÓN DE LA PRIMERA JUNTA ASESORA DEL JARDÍN CHARLES H. LANKESTER
}

\author{
Rafael Lucas Rodríguez Caballero $\dagger$ \\ Escuela de Biología, Universidad de Costa Rica
}

Se necesitó 40,000,000 de años de la accidentada trayectoria geológica de esta región para formar el istmo centroamericano que conocemos y la ación del tibio, violento y húmedo clima del caribe para dar forma en él al paisaje natural, asombrosamente rico en especies y en números.

Se necesitó el alma de un hombre como Charles $\mathrm{H}$. Lankester, que al tiempo que contribuía a la destrucción inexorable de este paraíso natural, precio obligado del avance de la agricultura y del "progreso", fue por 3 generaciones amigo y compañero de los exploradores de la flora costarricense, supo disfrutar de su belleza y llegó a apasionarse per ella en todas sus formas, que viendo 30 años antes de la oleada de preocupación que hoy corre por el mundo, la destrucción inminente de tantas especies y de tantos paisajes, supo soñar en un abrigo, un refugio para el bosque que veía desaparecer y dedicarse a realizar ese sueño en este rincón que hoy recibe su nombre... esfuerzo que mantuvo hasta los últimos instantes de su vida.

Se necesitó la mirada sensitiva de varias personas, entre las que destacaron la Dra. Mildred E. Mathias, la Sra. Betty Marshall y muy conspicuamente, la orquideóloga Rebecca Tyson Northen, quien afortunadamente nos acompaña hoy, para empe ãr en un llamado para buscar el modo de conservar este jardín y continuar la labor que quedaba inconclusa al extinguirse aquella chispa de entusiasmo que alentaba en Don Carlos...

Se necesitó la devoción por todo lo que puede crecer y florecer y dar fruto, que alentaba en el corazón de otro inglés, Stanley Smith, manifestándose después de su deceso en un Fondo establecido para fomentar la horticultura dondequiera fuese posible, aún en tierras nunca visitadas por el, y cuyo director también nos acompaña... y las características generosidad y tendencia a la acción cooperativa del pueblo norteamericano, manifestándose en un llameo hecho por la Asociación Norteamericana de Orquideología por medio de su Fondo para Investigación y Educación, algunos de cuyos dirigentes hoy nos honran con su compañía... para reunir la suma necesaria y entregar este jardín a la Universidad de Costa Rica, la cual la aceptó comprometiéndose a mantener en él el ideal, la visión y el esfuerzo de Don Carlos Lankester.

Al reunirnos aquí para instalar la primera Junta Asesora del Jardín Carlos H. Lankester, rindamos homenaje a la belleza natural de nuestra tierra, que merece muchos esfuerzos más para su protección, a aquel individuo notable, Charles H. Lankester, quien mereció del pueblo que lo contara como uno de los suyos ["Don Carlos"], al amor por la horticultura de Stanley Smith, que desboradaba los bordes de su mundo para envolver la tierra entera en su entusiasmo y a esa fraternal generosidad de los orquideólogos norteamericanos, muchos de los cuales ni habían visitado Costa Rica ni pensaban llegar nunca a visitarla, pero supieron ayudar a lo que consideraban una causa digna de esfuerzo.

Que este homenaje de admiración, de recuerdo y gratitud nos guíe en el desarrollo futuro de este jardín.

\footnotetext{
* El manuscrito autógrafo de este discurso, pronunciado por el Dr. Rafael Lucas Rodríguez Caballero durante la ceremonia de inauguración del Jardín Botánico Lankester el 2 de marzo de 1973, ha sido amablemente proporcionado por sus herederos como contribución para las celebraciones del 40 Aniversario de la institución.
} 


\section{MARZO 2, 1973}

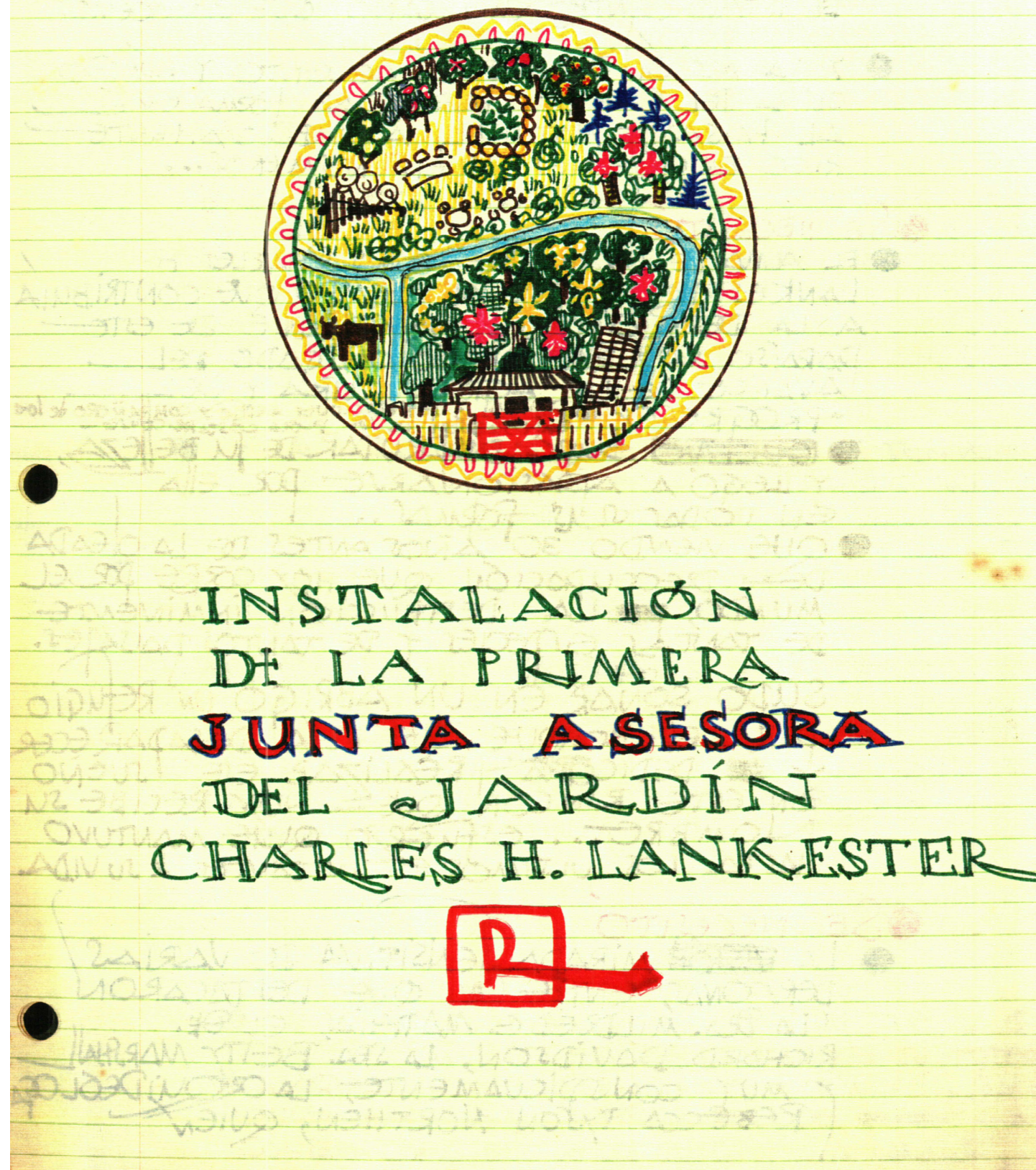

FIGURE 1. Primera página del manuscrito autógrafo de Rafael Lucas Rodríguez Caballero, con el discurso pronunciado en ocasión de la inauguración del Jardín Botánico Lankester. En la parte superior se aprecia un mapa estilizado del Jardín Botánico Lankester en el año 1973. Cortesía de los herederos de R. L. Rodríguez Caballero. 